\title{
EVALUATION OF VITALITY OF SARCOCYSTS IN BEEF BY THE DAPI FLUORESCENCE TEST
}

\author{
B. KOUDELA* and L. STEINHAUSER \\ *Department of Pathological Morphology and Parasitology, \\ Department of Food Hygiene and Technology, \\ University of Veterinary Science, 61242 Brno
}

Received November 16, 1983

\begin{abstract}
Koudela B., L. Steinhauser: Evaluation of Vitality of Sarcocysts in Beef by the DAPI Fluorescence Test. Acta vet. Brno, 53, 1984: 193-197.

Vitality of Sarcocystis sp. cystozoites in beef was evaluated by means of the DAPI fluorescence test. Results were verified by biological assays in definitive hosts. Sarcocysts remained vital in beef kept at refrigerator temperature over a period of 20 days after slaughter. They did not survive in frozen $\left(-18^{\circ} \mathrm{C}, 48\right.$ hours), cooked $\left(70^{\circ} \mathrm{C}\right.$, 10 min.), and pickled ( $12 \%$ sol. curing mixture, $12{ }^{\circ} \mathrm{C}, 72$ hours) meat.

Preliminary experiments with other protozoa indicate that the DAPI fluorescence test will meet application in different parasitological topics.
\end{abstract}

Cystozoite, fresh meat, chilled meat, frozen meat, cooked meat, pickled meat.

There are three species of the genus Sarcocystis known in muscle tissue of cattle. Their definitive hosts are different and so are apparently their pathogenic effects on the intermediate host: $S$. cruzi has the dog as definitive host and acts as pathogenic organism for cattle, $S$. hirsuta with the cat as definitive host is less pathogenic for the ox; $S$. hominis who has the man as definitive host, seems not to be pathogenic for the intermediate host.

Several ways have been designed how to evaluate vitality and infectivity of sarcocysts in beef meat. Gestrich and Heydorn (1974), Fayer (1975), Golubkov (1978), and Leek and Fayer (1978) performed assays in definitive hosts. Beside biological experiments, in vitro cultivation and dye-colouring by methylen or trypan blue were recommended (Bergler et al., 1980).

Our goal was to examine the availability of the DAPI fluorescence test fot the same purpose.

DAPI (4,6-diamidino-2-phenylindol) (SERVA FEINBIOCHEMICA) is a substance with soecific affinity to intracellular DNA and emits intensive fluorescence in the UV light (Russel et al., 1975). Schilling et al. (1979) and $\mathrm{Niemann}$ et al. (1981) worked with the DAPI fluorescence test to determine vitality of early embryonic stages in cattle and rabbit. After incubation of embrya with DAPI, nuclei of dead cells emitted fluorescence whereas the live ones did not. Russel et al. (1975) and Hyman and MacInnes (1979) based detecting of intracellular parasites, mycoplasms and viruses on the specific activity of DAPI to DNA.

\section{Materials and Methods}

Meat samples

From 10 at random chosen cows aged 3 to 5 years, samples of diaphragmal muscles and $\mathrm{m}$. longissimus dorsi were collected at each stage of meat processing:

A. Fresh meat

Samples of $100-150 \mathrm{~g}$ were collected one hour after slaughter.

B. Chilled meat

As the next step in meat processing, beef halves were cooled down to $16^{\circ} \mathrm{C}$ in the core by a stream of cold air in a quick-chilling tunnel for 10 hours, then cut to quarters and stored in the chilling 
room at $12^{\circ} \mathrm{C}$. To register the progress of meat ageing, $\mathrm{pH}$-values were measured by a needle electrode (ORION pH/temp., model 221). Meat samples were collected 6, 24, 48, 72 and 120 hours after slaughter. From day 5 to 20 , the samples were stored in a refrigerator at $4{ }^{\circ} \mathrm{C}$, and, examined in intervals of 3 days.

C. Frozen meat

Meat samples of $200-300 \mathrm{~g}$ each were sealed in PE-bags, frozen to $-18^{\circ} \mathrm{C}$ and kept at this temperature fo 48 hours. Thawing took place in a refrigerator at $4{ }^{\circ} \mathrm{C}$.

D. Heat-processed meat

Samples were considered cooked when temperature in the core remained at $70{ }^{\circ} \mathrm{C}$ for at least 10 minutes.

E. Pickled meat

Meat samples of $50-100 \mathrm{~g}$ each were pickled in a $12 \%$ solution of the standard curing mixture $\left(94 \% \mathrm{NaCl}, 0.5 \mathrm{NaNO}_{2}\right)$ over 72 hours ast $12{ }^{\circ} \mathrm{C}$.

\section{Isolation and purification of Sarcocystis sp. cystozoites}

In order to isolate cystozoites, meat samples were exposed to digestion in artificial peptic juice (Sharma and Dubey 1981) for 10 minutes, and, purified by means of the chromatographic gel Spheron (Koudela in press).

\section{DAPI fluorescence test}

As recommended by Niemann et al. (1981), DAPI was diluted with PBS (1:100.000). One drop of diluted DAPI was added to one drop of purified cystozoites suspended in phosphate buffered saline $\left(\mathrm{NaCl} 8,0 \mathrm{~g}, \mathrm{KCl} 0.2 \mathrm{~g}, \mathrm{Na}_{2} \mathrm{HPO}_{4} .12 \mathrm{H}_{2} \mathrm{O}, 3.21 \mathrm{~g}, \mathrm{KH}_{2} \mathrm{PO}_{4}, 0.2 \mathrm{~g}, \mathrm{H}_{2} \mathrm{O}\right.$ dest. ad $1000 \mathrm{ml}$ ), ( $\mathrm{pH} 7.2)$ and covered by a cover glass. Fluorescence was evaluated with the Soviet-made fluorescence microscope ML-2 in reflected light, at magnifications $200 \times$ and $450 \times$, with filtres FS $1-2$, S3S 7-2 (UV light $350 \mathrm{~nm}$ ). Emission was observed with the filtre ŽS 18 (480 nm and more). Cystozoites with an intensively fluorescent nucleus were classified as dead, those showing no fluorescence as live ones.

Effect of peptic juice on Sarcocystis sp. cystozoites

Vitality of cystozoites was evaluated after 60,90 , and 120 minutes of exposure to artificial peptic juice.

\section{Effect of meat processing on isolated cystozoites}

Cystozoites isolated from fresh meat were suspended in PBS and exposed to conditions imitating meat processing. They were examined after $5,10,15,20,25,30,45,60$, and 90 minutes of exposure to $55^{\circ} \mathrm{C}$ or $70^{\circ} \mathrm{C}$. Isolated cystozoites were kept at $-18^{\circ} \mathrm{C}$ for 48 hours and then examined. The effect of the nitrite curing mixture was evaluated after 72 hours of exposure.

\section{Verification of vitality of cystozoites by assays in definitive hosts}

To verify our classification of cystozoites, assays were carried out with four whelps aged two months and three kittens aged three months. Two pups and two kittens were fed meat from which isolated cystozoites displayed no fluorescence. Two pups and one kitten were fed meat from which isolated cystozoites emitted fluorescence. Parasitological examinations of their faeces were carried out daily over the period of 20 days.

\section{Results}

The evaluation of vitality of Sarcocystis sp. cystozoites is demonstrated in Table 1. Living cystozoites emitted no fluorescence, while there was an intensive fluorescence of nuclei in dead cystozoites. Fragments of cystozoites only could be isolated from frozen, cooked, or pickled meat samples. As far as there was a cell nucleus within the fragment, it emitted intensive fluorescence.

The process of isolation and purification had no effect on cystozoites. Their exposure to peptic juice for 120 minutes resulted in no alteration in vitality.

The effect of meat processing was illustrated by experiments with isolated cysto- 
zoites. Exposure to the temperature of $-18 \mathrm{C}$ for 48 hours affected the destruction of cystozoites. Likewise destroyed were cystozoites treated by the nitrite curing mixture. The effect of high temperature on isolated cystozoites is shown in Table 2.

Table 1

Vitality of Sarcocystis sp. cystozoites in differently processed beef

\begin{tabular}{|l|c|c|c|}
\hline \multirow{2}{*}{ Meat } & \multirow{2}{*}{ No. of samples } & \multicolumn{2}{|c|}{$\begin{array}{c}\text { Cystozoites of } \\
\text { Sarcocystis sp. }\end{array}$} \\
\cline { 2 - 4 } & & vital & dead \\
\hline Fresh & 10 & + & 0 \\
Chilled & 10 & + & 0 \\
Frozen & 10 & 0 & + \\
Cooked & 10 & 0 & + \\
Pickled & 10 & 0 & + \\
\hline
\end{tabular}

Table 2

Effect of temperature on vitality of isolated Sarcocysts sp. cystozoites from beef

\begin{tabular}{|c|c|c|}
\hline $\begin{array}{c}\text { Exposure to temperature } \\
\text { (minutes) }\end{array}$ & \multicolumn{2}{|c|}{ Percentage of dead cystozoites } \\
\cline { 2 - 3 } & at $55^{\circ} \mathrm{C}$ & at $70^{\circ} \mathrm{C}$ \\
\hline 5 & $3.4 \pm 4.87$ & $89.7 \pm 8.79$ \\
10 & $15.6 \pm 3.65$ & 100 \\
15 & $22.4 \pm 4.89$ & \\
20 & $27.6 \pm 5.23$ & \\
30 & $50.6 \pm 8.79$ & \\
45 & $78.9 \pm 9.79$ & \\
60 & $84.7 \pm 15.87$ & \\
90 & $96.7 \pm 8.96$ & \\
\hline
\end{tabular}

Whelps and kittens fed meat from which isolated cystozoites emitted no fluorescence, began elimination by day 11 . Animals fed meat from which isolated cystozoites emitted fluorescence, eliminated no sporocysts.

\section{Discussion}

The results of our evaluating vitality of sarcocysts by means of the DAPI fluorescence test are in agreement with the results achieved by biological assays carried out by Gestrich and Heydorn(1974), Fayer (1975), Golubkov (1978), and Leek and Fayer (1978).

Morphological and biological similarities of sarcocysts and Toxoplasma gondii suggest comparison with analogical assays on vitality and infectivity of toxoplasma cysts (Jacobs et al., 1960; Sommer et al., 1965; Dubey 1974). The vitality of toxoplasma cysts and sarcocysts in fresh, chilled, frozen and cooked meat is similar, and so is the survial of bradyzoites of Toxoplasma gondii and cystozoites of Sarcocystis sp. in peptic juice (Sharma and Dubey, 1981).

Determining vitality of cystozoites in beef after different processing is of considerable hygienic and epizootiological importance.

According to practical use of DAPI fluorescence test it is important to mention 
that nonspecific fluorescence was not observed. The only fragments of cystozoites with broken structure of cell components emitted weak fluorescence.

The intensity of fluorescence depends on the concentration of DAPI. While testing various concentrations of DAPI the concentration recommended by Niemann et al. (1981) (1:100 000) was found optimum.

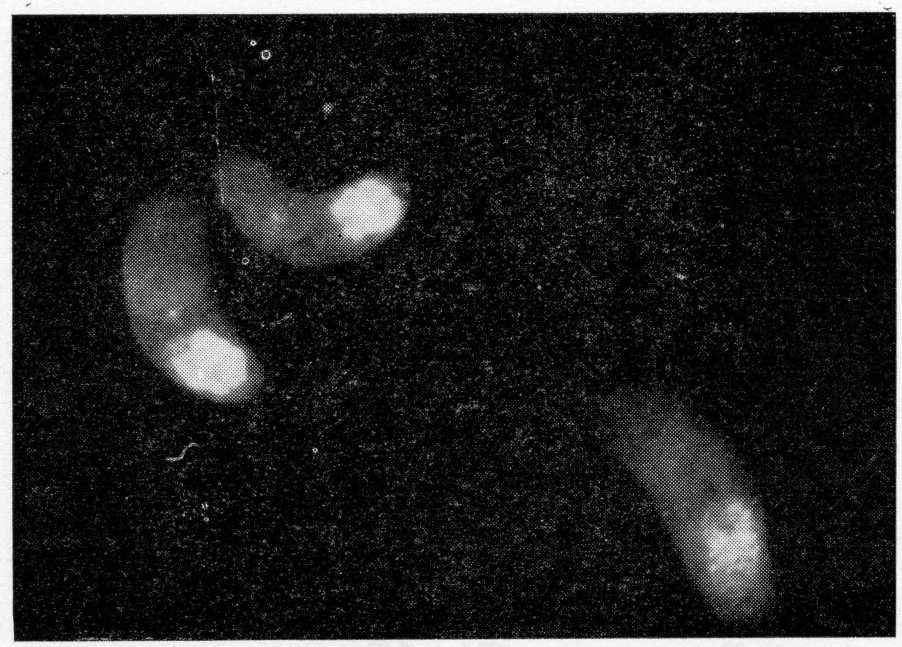

Fig. 1. Dead cystozoites with intensively fluorescent nuclei

The biological trials we presented here as well as assays reported by other authors confirmed the results achieved by the DAPI fluorescence test. Tentative assays with sporozoites of different coccidia (Eimeria tenella, Hammondia heydorni) and with cystozoites of Sarcocystis dispersa made it obvious that the DAPI fluorescence test might meet ample employment in parasitology.

\section{Posouzení životaschopnosti sarkocyst $\mathbf{v}$ hovězím mase fluorescenčním testem DAPI}

Posuzovali jsme životaschopnost cystozoitů Sarcocystis sp. v hovězím mase fluorescenčním testem DAPI. Výsledky posouzení jsme ověřovali biologickým pokusem na definitivních hostitelích. Sarkocysty přežívají v hovězím mase do 20. dne po poražení. $V$ mase mraženém $\left(-18^{\circ} \mathrm{C}, 48\right.$ hodin), tepelně opracovaném $\left(70^{\circ} \mathrm{C}, 10\right.$ minut $)$ a v mase lákovaném ( $12 \%$ roztok solící směsi, $12^{\circ} \mathrm{C}, 72$ hodin) sarkocysty nepřežívají.

Orientační posouzení životaschopnosti jiných protozoí ukazují na možnosti využití fluoresçenčního testu DAPI v parazitologii. 


\section{Оценка жизнеспособности саркокист в говядине флуоресцентным тестом ДАПИ}

Проводилась оценка жизнеспособности цистозоитов Sarcocystis sp., в говяжьем мясе флуоресцентным тестом ДАПИ. Резудьлтаты оценки проверялись биологическим әкспериментом на окончательном хозяине. Саркокисты переживают в говядине до 20 суток после убоя. В замороженном мясе ( $-18{ }^{\circ} \mathrm{C}, 48$ часов), термически обработанном $\left(70{ }^{\circ} \mathrm{C}, 10\right.$ минут) иі в мясе в рассоле $\left(12 \%\right.$ рассол, $12{ }^{\circ} \mathrm{C}, 72$ часа) саркокисты не переживают.

Ориентировочная оценка жизнеспособности других протозов свидегельствуег о возможности использования флуоресцентного теста ДАПИ в паразитологии.

\section{References}

BERGLER, K. G. - ERBER, M. - BOCH, J.: Untersuchungen zur Überlebensfähigkeit von Sporozysten bzw. Oozysten von Sarcocystis, Toxoplasma, Hammondia und Eimeria unter Labor- und Freiland- bedingungen. Berl. Münch. Tierärztl. Wschr. 93, 1980, 288-293.

BOX, E. D. - McGUINNES, T. B.: Sarcocystis in beef from retail outles demonstrated by digestion technique. J. Parasitol. 64, 1978, 161-162.

DUBEY, J. P.: Effect of freezing on the infectivity of Toxoplasma cysts to cats. J. Am. Vet. Med. Assoc. 155, 1974, 534-536.

FAYER, R.: Effect of refrigeration, cooking and freezing on Sarcocystis in beef from food stores. Proc. Helminth. Soc. Wash. 42, 1975, 138-140.

GESTRICH, R. - HEYDORN, A. O.: Untersuchungen zur Überlebensdauer von Sarkosporidienzysten im Fleisch von Schlachttieren. Berl. Münch. Tierärztl. Wschr. 87, 1974, 475-476.

GOLUBKOV, V. I.: Ustojčivost sarkocyst k někotorym faktoram. Veterinarija 5, 1978, 98-99.

HYMAN, B. C. - MacINNES, A. J.: Rapid detection of malaria and other bloodstream parasites by fluorescence microscopy with 4,6-diamidino-2-phenylindole (DAPI). J. Parasitol. 65, 1979, $421-425$.

JACOBS, L. - REMINGTON, J. S. - MELTON, M. L.: The resistence of encysted form of Toxoplasma gondii. J. Parasitol. 46, 1960, 11-21.

KOUDELA, B.: Purification of Sarcocystis sp. cystozoites by means of chromatographic gel Spheron. (in press)

LEEK, R. G. - FAYER, R.: Infectivity of Sarcocystis in beef and beef products from a retail store. Proc. Helmint. Soc. Wash. 45, 1978, 135-136.

LUKESSOVÁ, D.: Parasitological problems of sarcocystis in cattle and pigs. C.Sc. dissertation thesis. Vysoká škola veterinární. Brno $1982,144 \mathrm{pp}$.

NIEMANN, H. - SCHILLING, E. - SACHER, B. - SCHMIDT, D.: Der FDA- und DAPI-Test. Ein Beitrag zur Vitalitätbeurteilung von Rindembryonen mit Hilfe der Fluoreszenzmikroskopie. Berl. Münch. Tierärztl. Wschr. 94, 1981, $441-445$.

RUSSEL, W. C. - NEWMAN, C. - WILLIAMSON, D. H.: A simple cytochemical technique for demonstration of DNA in cells infected with mycoplasmas and viruses. Nature 253, 1975, $461-462$.

SCHILLING, E, - NIEMANN, S. - CHENG, P. - DOEPKE, H. H.: DAPI - a further fluorescence test for diagnosing the viability of early cow and rabbit embryos. Zuchthygiene 14, $1979,170-172$.

SHARMA, S. P. - DUBEY, J. P.: Quantitative survival of Toxoplasma gondii tachyzoites and bradyzoites in pepsin and in trypsin solutions. A m. J. Vet. Res. 42, 1981, 128-130.

SOMMER, R. - ROMMEL, H. - LEWETZOW, R.: Die Überlebensdauer von Toxoplasmazysten in Fleisch und Fleischzubereitungen. Die Fleischwirtschaft 45, 1965, 454-457. 